\title{
B cell adrenoceptors and sulphonylurea-induced insulin release in mouse islets
}

\author{
M. G. Garrino and J. C. Henquin \\ Unité de Diabétologie et Nutrition, University of Louvain, Faculty of Medicine, Brussels, Belgium
}

Summary. Interactions of tolbutamide and glibenclamide with B cell adrenoceptors have been reported. This study evaluated the possible role of such interactions in the stimulation of insulin release. Mouse islets were incubated in the presence of $10 \mathrm{mmol} / /$ glucose alone or with tolbutamide $(10 \mu \mathrm{mol} / \mathrm{l})$ or glibenclamide $(0.02 \mu \mathrm{mol} / \mathrm{l})$. At $0.01-$ $10 \mu \mathrm{mol} / 1$, blockers of $\alpha_{2}$-adrenoceptors (yohimbine, idazoxan) or $\alpha_{1}$-adrenoceptors (prazosin) had practically no effect on glucose-induced insulin release and did not affect its potentiation by sulphonylureas, except for a slight increase by $10 \mu \mathrm{mol} / 1$ prazosin and idazoxan. Nonspecific $\alpha$-blockers (phentolamine, dihydroergotamine) increased control release at $10 \mu \mathrm{mol} / 1$, but only the latter amplified the response to tolbutamide. Blockers of $\beta$-adrenoceptors were tested at $0.1-100 \mu \mathrm{mol} / \mathrm{l}$ : propranolol $\left(\beta_{1}, \beta_{2}\right)$, metoprolol $\left(\beta_{1}\right)$ and compound ICI 118-551 $\left(\beta_{2}\right)$. They increased glucose-induced insulin release at $100 \mu \mathrm{mol} / 1$ but variably altered the effect of sulphonylureas. Blockers of adrenoceptors have, thus, no effect on insulin release in vitro at therapeutic concentrations. At high concentrations, they non-specifically affect the action of sulphonylureas. We conclude that an interaction with $\mathrm{B}$ cell adrenoceptors is not involved in the insulinotropic action of sulphonylureas.

Key words: Insulin release, tolbutamide, glibenclamide, $\alpha$-adrenoceptors, $\beta$-adrenoceptors, isolated islets.
Tolbutamide and glibenclamide displace $\alpha$ - and $\beta$ adrenergic radioligands in islet cells [1], and blockers of $\alpha$ - and $\beta$-adrenoceptors have been reported to affect sulphonylurea-induced insulin release in man [2] or in dogs [3-5]. These observations raise the possibility that sulphonylureas may influence insulin release by interacting with adrenoceptors in B cells. To test this hypothesis, isolated mouse islets were stimulated here by tolbutamide and glibenclamide in the presence of specific or non-specific blockers of $\alpha$ - and $\beta$-adrenoceptors. The blockers were used at four concentrations, of which the lower two approximately encompass the therapeutic range, and the higher two are lethal [6].

\section{Materials and methods}

All experiments were performed with islets isolated after collagenase digestion of the pancreas of fed female NMRI mice $(25-30 \mathrm{~g})$. Immediately after isolation, the islets were preincubated for $45 \mathrm{~min}$ at $37^{\circ} \mathrm{C}$, in a medium containing $10 \mathrm{mmol} / 1$ glucose. Batches of three islets were then incubated for $60 \mathrm{~min}$ in $1 \mathrm{ml}$ of medium containing $10 \mathrm{mmol} / \mathrm{l}$ glucose alone or with tolbutamide $(10 \mu \mathrm{mol} / 1)$ or glibenclamide $(0.02 \mu \mathrm{mol} / \mathrm{l})$, and appropriate concentrations of test compounds. At the end of the incubation a portion of the medium was diluted for measurement of immunoreactive insulin with rat insulin as standard [7].

The medium used had the following ionic composition $(\mathrm{mmol} / \mathrm{l})$ : $\mathrm{NaCl} 120, \mathrm{KCl} 4.8, \mathrm{CaCl}_{2} 2.5, \mathrm{MgCl}_{2} 1.2, \mathrm{NaHCO}_{3} 24$. It was gassed with $\mathrm{O}_{2} / \mathrm{CO}_{2}(94: 6)$ to maintain a $\mathrm{pH}$ of 7.4 , and was supplemented with bovine serum albumin $(1 \mathrm{mg} / \mathrm{ml})$.

The sources of test substances were as follows: tolbutamide and glibenclamide (Hoechst A.G., Frankfurt, FRG); dihydroergotamine (Sandoz Pharmaceuticals, Basel, Switzerland); phentolamine mesilate (Ciba-Geigy, Basel, Switzerland); prazosin hydrochloride (Pfizer, Brussels, Belgium); yohimbine hydrochloride (Aldrich Europe, Beerse, Belgium); idazoxan (Reckitt \& Colman, Kingston, UK); dl-propranolol and compound ICI 118-551 (ICI Ltd, Macclesfield, UK); metoprolol (Astra Nobel Pharma, Brussels, Belgium). All other reagents were from Merck AG (Darmstadt, FRG).

\section{Statistical analysis}

Results are presented as means \pm SEM for the indicated number of batches of islets, obtained from four different islet preparations. All data were submitted to a two-way analysis of variance to assess the interaction between tolbutamide or glibenclamide and each test substance. The statistical significance of the effects of each test substance, with or without sulphonylurea, was then assessed by a test of Dunnett. 


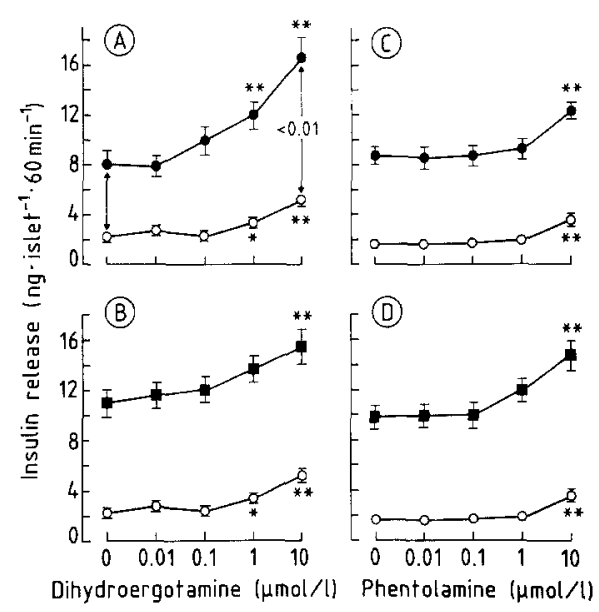

Fig. 1A-D. Effects of dihydroergotamine and phentolamine (nonspecific blockers of $\alpha$-adrenoceptors) on sulphonylurea-induced insulin release by mouse islets. The islets were incubated in the presence of $10 \mathrm{mmol} / \mathrm{lglucose}$ alone $(\mathrm{O})$, or with $10 \mu \mathrm{mol} / \mathrm{l}$ tolbutamide ( $\bullet$ in $\mathbf{A}$ and $\mathbf{C}$ ) or $0.02 \mu \mathrm{mol} / \mathrm{l}$ glibenclamide ( $\boldsymbol{\square}$ in $\mathbf{B}$ and $\mathbf{D}$ ). Statistically significant effects of the blockers, in the presence or absence of sulphonylurea, are shown by $* p<0.05$ or $* * p<0.01$. Vertical arrows with $p$ value indicate at which concentration of the blocker a significant interaction with the effect of the sulphonylurea was observed. Values are means \pm SEM for 21 batches of islets

\section{Results}

Insulin release by control islets amounted to $1.49 \pm 0.07 \mathrm{ng} \cdot$ islet $^{-1} \cdot 60 \mathrm{~min}^{-1}(n=157)$ in the presence of $10 \mathrm{mmol} / 1$ glucose alone, to $6.53 \pm 0.25 \mathrm{ng} \cdot$ islet $^{-1}$. $60 \mathrm{~min}^{-1}(n=154)$ when the medium was supplemented with $10 \mu \mathrm{mol} / \mathrm{l}$ tolbutamide, and to $8.43 \pm 0.37 \mathrm{ng} \cdot$ islet $^{-1}$. $60 \min ^{-1} \quad(n=101)$ when the medium contained $0.02 \mu \mathrm{mol} / \mathrm{l}$ glibenclamide.

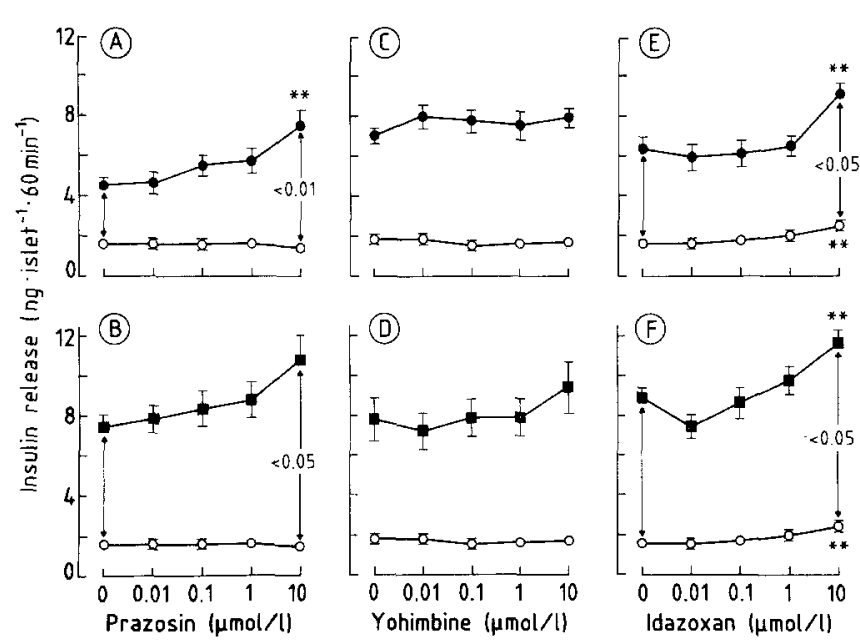

Fig. 2 A-F. Effects of prazosin (specific blocker of $\alpha_{1}$-adrenoceptors), and of yohimbine and idazoxan (specific blockers of $\alpha_{2}$ adrenoceptors) on sulphonylurea-induced insulin release by mouse islets. The islets were incubated in the presence of $10 \mathrm{mmol} / \mathrm{l}$ glucose alone (O), or with $10 \mu \mathrm{mol} / \mathrm{l}$ tolbutamide ( $\bullet$ in $\mathbf{A}, \mathbf{C}$ and $\mathbf{E}$ ) or $0.02 \mu \mathrm{mo} / / 1$ glibenclamide ( $\boldsymbol{\square}$ in $\mathbf{B}, \mathbf{D}$ and $\mathbf{F}$ ). Statistically significant effects of the blockers, in the presence or absence of sulphonylurea are shown by *** $p<0.01$. Vertical arrows with $p$ value indicate at which concentration of the blocker a significant interaction with the effect of the sulphonylurea was observed. Values are means \pm SEM for 19-21 batches of islets
Insulin release induced by glucose alone was slightly increased by high concentrations of non-specific blockers of $\alpha$-adrenoceptors: $1-10 \mu \mathrm{mol} / \mathrm{l}$ dihydroergotamine and $10 \mu \mathrm{mol} / 1$ phentolamine (Fig. 1). Both blockers had essentially similar effects when release was potentiated by tolbutamide or glibenclamide. Only $10 \mu \mathrm{mol} / 1$ dihydroergotamine significantly enhanced the effect of tolbutamide (Fig. 1A).

Prazosin, a specific blocker of $\alpha_{1}$-adrenoceptors, was without effect on glucose-induced insulin release, but slightly increased the potentiating action of tolbutamide and glibenclamide at the high concentration of $10 \mu \mathrm{mol} / \mathrm{l}$ (Fig. 2A and B). Yohimbine, a specific blocker of $\alpha_{2}$ adrenoceptors, had no influence on the insulin response to glucose alone nor on its potentiation by sulphonylureas (Fig. 2C and D). Idazoxan, another specific blocker of $\alpha_{2-}$ adrenoceptors, slightly increased glucose-induced insulin release and its potentiation by tolbutamide or glibenclamide, at least at the concentration of $10 \mu \mathrm{mol} / 1$ (Fig. 2 Eand F).

Glucose-induced insulin-release was increased fivefold by $100 \mu \mathrm{mol} / \mathrm{l}$ propranolol, a non-specific blocker of $\beta$-adrenoceptors. The potentiating effect of tolbutamide was also amplified by $10-100 \mu \mathrm{mol} / \mathrm{l}$ propranolol and that of glibenclamide by $100 \mu \mathrm{mol} / \mathrm{l}$ propranolol (Fig. $3 \mathrm{~A}$ and B). Metoprolol, a specific blocker of $\beta_{1}$-adrenoceptors, increased both glucose-induced insulin release and its potentiation by the two sulphonylureas only when used at the high concentration of $100 \mu \mathrm{mol} / \mathrm{l}$ (Fig. $3 \mathrm{C}$ and D). Compound ICI 118-551, a specific blocker of $\beta_{2}$-adrenoceptors, had complex effects on insulin release. At the concentrations of 10 and $100 \mu \mathrm{mol} / \mathrm{l}$, it enhanced the response to glucose. It also amplified the potentiating action of tolbutamide and glibenclamide at $10 \mu \mathrm{mol} / \mathrm{l}$. However, this positive effect was not observed at $100 \mu \mathrm{mol} / 1$, a con-

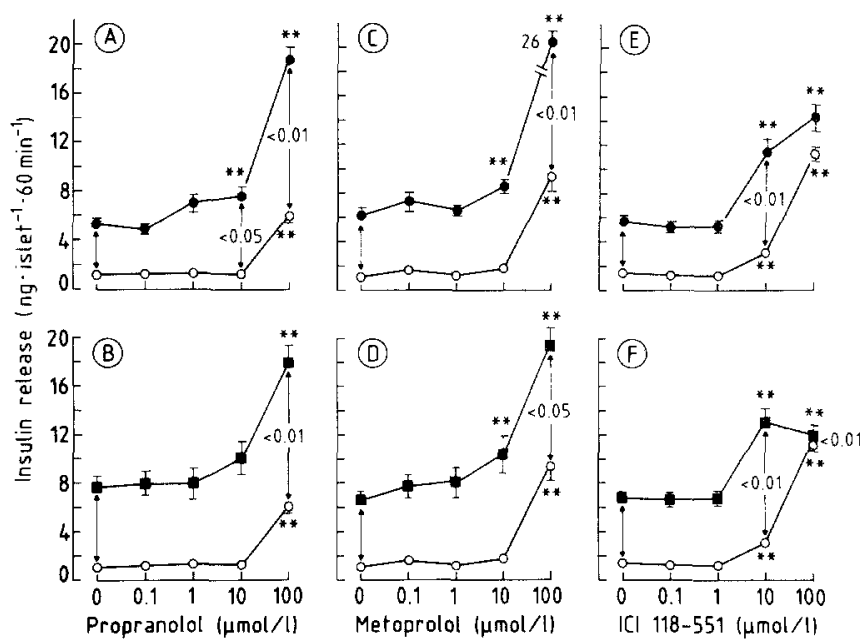

Fig. 3A-F. Effects of propranolol (non-specific blocker of $\beta$-adrenoceptors), of metoprolol (specific blocker of $\beta_{1}$-adrenoceptors) and of compound ICI 118-551 (specific blocker of $\beta_{2}$-adrenoceptors) on sulphonylurea-induced insulin release by mouse islets. The islets were incubated in the presence of $10 \mathrm{mmol} / \mathrm{l}$ glucose alone $(O)$, or with $10 \mu \mathrm{mol} / \mathrm{l}$ tolbutamide ( $\bullet$ in $\mathbf{A}, \mathbf{C}$ and $\mathbf{E}$ ) or $0.02 \mu \mathrm{mol} / /$ glibenclamide ( $\boldsymbol{\nabla}$ in $\mathbf{B}, \mathbf{D}$ and $\mathbf{F}$ ). Statistically significanteffects of the blockers, in the presence or absence of sulphonylurea are shown by $* * p<0.01$. Vertical arrows with $p$ value indicate at which concentration of the blocker a significant interaction with the effect of the sulphonylurea was observed. Values are means \pm SEM for 18-22 batches of islets 
centration that even inhibited the response to glibenclamide (Fig. 3E and F).

\section{Discussion}

Both functional and binding studies have established that $B$ cells are equipped with $\alpha_{2}$-adrenoceptors $[8,9]$. $\beta$ adrenoceptors have been identified on islet cells [10], but their presence on B cells has been questioned [11]. In our freshly isolated islets, $\beta$-agonists have no effect on glucose-induced insulin release, whereas as little as $1 \mathrm{nmol} / \mathrm{l}$ adrenaline inhibits it by about one third (unpublished data). Moreover, the $85 \%$ inhibition produced by $100 \mathrm{nmol} / \mathrm{l}$ adrenaline is completely prevented by $1 \mu \mathrm{mol} / \mathrm{l}$ yohimbine [12]. This sensitivity is similar to that of cultured purified B cells [11].

It has long been known that high concentrations of phentolamine $(\approx 35 \mu \mathrm{mol} / \mathrm{l})$ [13] and propranolol $(\approx 200 \mu \mathrm{mol} / 1)[14]$ increase insulin release in vitro. This is confirmed in the present study which further shows that other, though not all, $\alpha$ - and $\beta$-blockers increased release at concentrations of $10-100 \mu \mathrm{mol} / \mathrm{l}$. As these effects are unlikely to be specific, the underlying mechanisms were not investigated. A recent study has clearly shown that the stimulation of insulin release by $31 \mu \mathrm{mol} / 1$ phentolamine is not due to blockade of $\alpha$-adrenoceptors [15].

Binding studies have suggested that tolbutamide has a greater affinity for $\beta$-adrenoceptors and glibenclamide for $\alpha$-adrenoceptors [1]. Our data did not reveal any preferential interaction of blockers of one type of adrenoceptors with one of the two sulphonylureas. Phentolamine and dihydroergotamine have been reported as amplifying tolbutamide-induced insulin release in vivo $[3,5]$. Although we observed a similar effect in vitro with dihydroergotamine, this interaction cannot be taken as evidence of a role for $\alpha$-adrenoceptors in the response to sulphonylureas. Thus, it was not observed with all blockers and did not show specificity for $\alpha_{1}$ - or $\alpha_{2}$-adrenoceptors. Propranolol has been reported as decreasing tolbutamide-induced insulin release in vivo $[2,4]$. No such effect was found in vitro. On the contrary, high concentrations of propranolol augmented the insulin response to tolbutamide and glibenclamide. The significance of this interaction is unclear since it was also observed with specific blockers of $\beta_{1}$ - and $\beta_{2}$-adrenoceptors.

In conclusion, interactions between tolbutamide or glibenclamide and blockers of adrenoceptors only occur at very high concentrations of the latter and appear to be non-specific. As these concentrations are never reached in vivo [6], no similar drug interactions at the $B$ cell level should be anticipated in treated patients. Our results do not support the suggestion [1] that B cell adrenoceptors play a role in the stimulation of insulin release by sulphonylureas. On the other hand, they indirectly add to the evidence that $\mathrm{K}^{+}$channels of the $\mathrm{B}$ cell membrane are the sole target for these drugs [16-19].

Acknowledgements. This work was supported by grant 3.4546 .86 from the FRSM, Brussels. M. G. G. is recipient of a fellowship from the Fondation Horlait-Dapsens, Brussels. J.C.H. is "Directeur de Recherches" of the FNRS, Brussels. We thank Mr. M. Gérard for skilled assistance and Miss M. Nenquin for editorial help.

\section{References}

1. Cherksey B, Altszuler N (1984) Tolbutamide and glyburide differ in effectiveness to displace $\alpha$ - and $\beta$-adrenergic radioligands in pancreatic islet cells and membranes. Diabetes 33: 499-503

2. Massara F, Strumia E, Camanni F, Molinatti GM (1971) Depressed tolbutamide-induced insulin response in subjects treated with propranolol. Diabetologia 7:287-289

3. Sirek A, Sirek OV, Policova Z (1974) Dihydroergotamine: a potent biological amplifier of sulphonylureas. Diabetologia 10 : $267-270$

4. Sirek OV, Sirek A, Policova Z (1975) Inhibition of sulphonylurea-stimulated insulin secretion by beta adrenergic blockade. Diabetologia 11: 269-272

5. Hampshire J, Moraru E, Rathgeb I, Schwartz J, Altszuler N (1978) Phentolamine potentiates tolbutamide-induced insulin secretion and hypoglycemia. Fed Proc 37:628

6. Reynolds JEF (ed) (1989) Martindale - The extra pharmacopoeia. The Pharmaceutical Press, London, pp 1-1896

7. Henquin JC, Lambert AE (1975) Cobalt inhibition of insulin secretion and calcium uptake by isolated rat islets. Am J Physiol 228: 1669-1677

8. Nakaki T, Nakadate T, Kato R (1980) $\alpha_{2}$-adrenoceptors modulating insulin release from isolated pancreatic islets. NaunynSchmiedeberg's Arch Pharmacol 313:151-153

9. Cherksey B, Mendelsohn S, Zadunaisky J, Altszuler N (1982) Demonstration of $\alpha_{2}$-adrenergic receptors in rat pancreatic islets using radioligand binding. Proc Soc Exp Biol Med 171: 196-200

10. Fyles JM, Cawthorne MA, Howell SL (1986) The characteristics of $\beta$-adrenergic binding sites on pancreatic islets of Langerhans. J Endocrinol 111:263-270

11. Schuit FC, Pipeleers DG (1986) Differences in adrenergic recognition by pancreatic A and B cells. Science 232: 875-877

12. Drews G, Debuyser A, Nenquin M, Henquin JC (1990) Galanin and epinephrine act on distinct receptors to inhibit insulin release by the same mechanisms including an increase in $\mathrm{K}^{*}$ permeability of the B-cell membrane. Endocrinology 126

13. Efendic S, Cerasi E, Luft R (1975) Effect of phentolamine and preperfusion with glucose on insulin release from the isolated perfused pancreas from fasted and fed rats. Diabetologia 11: $407-410$

14. Northrop G, Ryan WG, Schwartz TB (1973) Propranolol-induced insulin release in isolated rat islets of Langerhans. Diabetes 22: 91-93

15. Schulz A, Hasselblatt A (1988) Phentolamine, a deceptive tool to investigate sympathetic nervous control of insulin release. Naunyn-Schmiedeberg's Arch Pharmacol 337: 637-643

16. Henquin JC (1980) Tolbutamide stimulation and inhibition of insulin release: studies of the underlying ionic mechanisms in isolated rat islets. Diabetologia 18: 151-160

17. Garrino MG, Schmeer W, Nenquin M, Meissner HP, Henquin JC (1985) Mechanism of the stimulation of insulin release in vitro by HB 699, a benzoic acid derivative similar to the non-sulphonylurea moiety of glibenclamide. Diabetologia 28: 697-703

18. Sturgess NC, Ashford MLJ, Cook DL, Hales CN (1985) The sulphonylurea receptor may be an ATP-sensitive potassium channel. Lancet II: 474-475

19. Panten U, Burgfeld J, Goerke F, Rennicke M, Schwanstecher M, Wallasch A, Zünkler BJ, Lenzen S (1989) Control of insulin secretion by sulphonylureas, meglitinide and diazoxide in relation to their binding to the sulfonylurea receptor in pancreatic islets. Biochem Pharmacol 38: 1217-1229

Received: 1 August 1989

and in revised form: 16 November 1989

Dr. J.C.Henquin

Unité de Diabétologie et Nutrition

UCL 54.74

Avenue Hippocrate, 54

B-1200 Brussels, Belgium 